УДК 37.02:004.9

Valeriy Yu. Bykov

Doctor of Technical Sciences, Professor, Academician of NAES of Ukraine, director Institute of Information Technologies and Learning Tools of NAES of Ukraine, Kyiv, Ukraine bykov@iitlt.gov.ua

Mariya P. Leshchenko

Doctor of Educational Sciences, Professor, Leading Researcher

Institute of Information Technologies and Learning Tools of NAES of Ukraine, Kyiv, Ukraine

leschenko@iitlt.gov.ua

\title{
DIGITAL HUMANISTIC PEDAGOGY: RELEVANT PROBLEMS OF SCIENTIFIC RESEARCH IN THE FIELD OF USING ICT IN EDUCATION
}

\begin{abstract}
In the article theoretical and methodological principles of digital humanistic pedagogy - the science about the laws of creating a positive integrated educational reality as a result of the convergence of physical and virtual (created using ICT) training spaces (environments) are determined. Based on the use of modern ICT learning activity (formal, nonformal and informal) is at the intersection of two worlds: the real and the virtual. Methodology and research methods of classical pedagogy require review and improvement in the context of current realities of the educational process, needs and interests of all its subjects.

The development of digital humanities in the international educational space is analyzed; the content of the new field of pedagogical knowledge as part of digital humanistic is outlined; research methods and directions of current scientific research are defined.
\end{abstract}

Keywords: humanities; digital technologies; ICT; integration; digital humanistic pedagogy; methodological principles; pedagogical reality; cognitive and active field; quality of education.

\section{INTRODUCTION}

The problem in general. Intensive expansion of ICTs in education at the same time is characterized by insufficient implementation of their powerful educational potential, in particular for development of cognitive, creative, cultural, linguistic, and social competencies of an individual; creation and management systems of health keeping and research training. As a result of it, there is an urgent need to understand the theoretical and methodological basis of the educational process in which ICTs are used. Of particular importance is the improvement of pedagogical skills of teachers at all levels of lifelong education concerning the use of ICT to improve the quality of teaching, and give it the properties of democracy, openness, personalization, creativity, creating area of attractiveness in the eyes of students, teachers, and motivating everyone to informative and educational activities. Expectations of scientists to create concepts of combination of humanistic and technological components of the educational process are related to pedagogy.

Informatization of system of national education was carried out thanks to the selfless activity of outstanding Ukrainian scientists such as V. Bykov, M. Zhaldak and others, as well as of students of scientific schools $[2 ; 3 ; 6 ; 7]$. The introduction in Ukraine of a new specialty "ICT in Education" for the candidate and doctor degrees of Pedagogy marked not only the distinguishing of a new research field, but also announced the breaking out of a new era in the development of national pedagogy - the integration of education and pedagogical events with digital technologies, that permeates all areas of pedagogical knowledge: theory and history of pedagogy, didactics, theory of education, education management, pedagogy of lifelong education, vocational and special pedagogy and etc. [15] 
Analysis of topics and subjects of successful doctorate and candidate theses in specialty 13.00.10 "Information and Communication Technologies in Education" outlines a fairly wide range of scientific studies:

- ICT in educational process in secondary school;

- ICT in teacher education;

- ICT in vocational education;

- ICT in educational management [1].

The character of these scientific papers proves that the subject of the research is the study of educational phenomena occurring in educational reality, which includes physical and virtual (created using ICT) spaces. Based on the use of modern ICT learning activity (formal, nonformal and informal) is at the intersection of two worlds: the real and the virtual. Methodology and methods of educational research of classical pedagogy require revision and improvement in the context of current realities of educational process, needs and interests of all its participants.

Limited use of pedagogical potential of ICT is caused by insufficient awareness of pedagogical society about the possibility of using technology for individualization of learning, cognitive and creative development of students, coordination of interaction in solving educational and research, organizational and administrative tasks etc. In our opinion, theoretical and practical grounds of a new branch of pedagogical knowledge - digital humanistic pedagogy may improve situation. This pedagogy integrates -bio and -techno and explains how to organize educational process if it takes place in real and virtual space.

Analysis of recent studies. In national educational thought the problems of humanization of education and humanization of educational process based on widespread use of ICT were firstly presented by M. Zhaldak [6]. The scientist rightly emphasizes that the problems of informatization of educational process are "complex and above all they are educational problems", and their solution, according to the scientist, «requires development of new computer-oriented methodical systems of teaching of all subjects - new teaching content, new tools, organizational forms and methods of education, training, maintenance, analysis, adjustment of educational process, learning management, aimed at significant deviation in independent, research, and creative learning activities of students and teachers on the basis of wide and pedagogically prudent use along with traditional, new computer-oriented technologies of education, activation of cognitive activity of students and teachers, and at a considerable intensification of communication of students and teachers, and educational process ..." [7]. In fact, academic M. Zhaldak outlined the content of a new field of pedagogical knowledge that goes far beyond of school course of Informatics and covers the whole educational process.

The studies of the scientists such as V. Bykov [2], V. Kremen [8] are dedicated to the problems of open education, educational space, educational environment in the information society. The use of ICT as tools of increasing the positive potential of cognitive and active field created by a teacher, the ways of virtualization of educational process, giving it creative characteristics are studied in the works of M. Leshchenko [11]. The component structure of IC competences of a teacher is quite detailed analyzed in the works of O. Ovcharuk [13], O. Spirin [16] and others.

The problems of development of digital humanistic pedagogy are highlighted in the works of foreign pedagogies: P. Anderson [19], O. Bjork [21], J. Brier [22], T. Clement [23], C. Davidson [24], P. Fyfe [28], B. Hirsch [26], D. Jakacki [29], R. Lanham [35], S. Warnock [40], R. Whitson [41]. At the same time, the theoretical bases of digital humanistic pedagogy that explores the rules of creation of positive educational reality through ICT require coverage. 
Article's goal is a study of theoretical principles of digital humanistic pedagogy - the science about the laws of creating a positive integrated educational reality as a result of the convergence of physical and virtual (created using ICT) training spaces (environments).

\section{METHODS OF THE STUDY}

In our study we use the following methods: theoretical - analysis of philosophical, pedagogical, psychological and technological literature making it possible determine the essence of the basic concepts of research, systematization and generalization of theoretical and empirical data by which the theoretical background of digital humanistic pedagogy is revealed; empirical - pedagogical observation, netnography based on the development of content, forms and methods of digital humanistic pedagogy.

\section{PRESENTATION OF THE MAIN RESEARCH}

We intend to analyze foreign experience, in particular of highly developed countries, to determine the theoretical and methodological principles, content and tools of digital humanistic pedagogy. New pedagogical category acquired scientific evidence in 2012 after the publication of a collection of scientific papers "Digital humanistic education: practice, principles, policies", edited by B. D. Hirsch (Brett D. Hirsch) [26].

This is impressive and important collection of scientific papers on different aspects of pedagogy in digital humanities, which enables timely response to the urgent questions of theory and practice of digital humanistic pedagogy. The publication was positively evaluated by leading scientists and artists:

- This collection makes an important contribution to the development of digital pedagogy and gives it a more suitable and high status which it deserves (Kathleen Fitzpatrick, Director of Scholarly Communication, Modern Language Association);

- I really appreciate this edition because the semantic richness and thoroughness of investigations serve as a substantiation of further prospects. I would certainly suggest this book to each teacher who uses ICT in the humanitarian field, especially at the university level (Kathleen Fitzpatrick, Director of Scholarly Communication, Modern Language Association);

- In general, this book is a very necessary resource for digital humanities communities. It not only introduces a reader to the field of unknown to many teachers and students digital humanitarian issues, but also provides information on the use of computer technologies in the humanitarian field, activities in various scientific and educational institutions (Julian Dettori, British Journal of Educational Technology) [26].

The statement issued by American scientists sounds reasonable that "the future and education in the future will be digital ... so it is irresponsible to use ICT in education without defining principles of digital humanistic pedagogy. There are various ways of structuring digital humanistic pedagogy, among which the most effective one is to tear away from the computer and to think over this problem" [28]. This figurative statement emphasizes that the object of digital pedagogy's study is the impact of ICT on all participants of educational process, the research of educational and cognitive actions taking place both in material and virtual reality and according to it the design of content, forms and methods of teaching.

According to B.D. Hirsch, digital humanistic pedagogy is "the heart of digital humanities" [26; 16]. This figurative definition points to the origins of a new field of pedagogical knowledge. Thus, the origins of digital humanistic pedagogy are found in digital humanities - interdisciplinary field of scientific researches and educational practices that emerged at the intersection of computer and humanities. 
Digital humanities (often abbreviated DH), developed from computerization of humanitarian field and digital humanities practices, cover a variety of topics from creation and storage of online collections of artifacts to collection of cultural data bases. Digital humanities also include converted into digital and created digital materials and combine methodology of traditional humanities disciplines (such as history, philosophy, linguistics, literature, art, archeology, music and culture) and social sciences with computer technologies (for example, data visualization, information search, data collection, statistics, writing text, digital cartography, digital publication) [20; 26].

Unlike many other interdisciplinary experiments, digital humanities have a very wellknown beginning .In 1949, Father Roberto Busa - an Italian Jesuit priest, set a goal to analyze by technical means the complete collection of letters of Thomas Aquinas - an Italian theologian of the XIII century, and found The Index Thomisticus, which would be a complete concordance of all 10.6 million words of Thomas Aquinas.

The solution of this problem without the use of a certain type of technical equipment was impossible. The work started using punch cards and sorting machines, was practically completed in 33 years, on the base of large universal IBM computers [26].

The methodological basis of digital humanities is the use of ideas that have emerged in the main stream of technocratic sciences. This important approach for humanities and computer sciences proves the creation of unifying concepts that cover bios and techno. Digital humanities also overlap with research of new media and information sciences, media theory of composition, studying of computer games. Mastering digital humanistic skills takes place in the course of creation and implementation of research projects of an interdisciplinary nature.

The conceptual tools of digital humanities to express the artistic and social activities of an individual are the new information and communication technologies, including the Internet, changing the nature of many information sources (letter $\rightarrow$ e-mail, book $\rightarrow$ e-book, audiobook; traditional library $\rightarrow$ electronic library, encyclopedia $\rightarrow$ Wikipedia etc.).

Specialists in digital humanities have been trained at the levels of bachelor, master and doctoral degree programs at universities of Britain, Canada and the United States since 2005 [20; 26]. They have started Bachelors'training in major "Humanities of the second generation: humanities 2.0" in Poland. Thus, in 2013 Kazimierz Wielki University in Bydgoszcz opened a new training course called "Humanities of the second generation" (Humanistyka drugiej generacji). The offer is addressed to those candidates who want to realize their ideas and skills through the development and use of various Internet resources.

The website of the university notes that "Humanities 2.0" is a growing opportunity not only for communication, entertainment or business (social media, Internet journalism, games, e-commerce), but it also provides unlimited resources for development and education. Therefore, in 2013/2014 management of Kazimierz Wielki University decided to open a new major at the Faculty of Humanities that will train specialists. The university offers four majors to the candidates: "Information society and digitization"; "Internet journalism and social media"; "(E)-letter and computer editing"; "Research and development of computer games" [31].

We would like to note that as a result of cooperation of the Jan Kochanowski University in Kielce, in particular Branches in Piotrków Trybunalski (Poland) with Institute of Information Technologies and Learning Tools of NAPS of Ukraine, training of specialists in majors "History 2.0", "Philology 2.0", "Pedagogy 2.0"has started [39].

The development of digital humanities is one of the major trends in the world educational space, and it confirms the functioning of the international scientific and educational organizations that support development of integration processes in the humanistic and digital sectors. 
The Alliance of Digital Humanities Organizations (ADHO) is an organization whose objectives are to promote and support digital research on the use of ICT in teaching arts and humanities, coordinating interaction between humanists and humanitarians involved in digital and computer-oriented research, teaching, creating and disseminating valuable experience in all areas presented by the variety of membership.

The Alliance of Digital Humanities Organizations (ADHO) supports initiatives for publications, presentations, cooperation and training; recognizes and supports best practices in these activities, and acts as a public advisory force. Thus, ADHO embraces and coordinates relevant activities through constituent organizations: the European Association for Digital Humanities (EADH, founded in 1973 as the Association for Literary and Linguistic computerization), the Association for Computers and the Humanities ( $\mathrm{ACH}$, established in 1978), the Canadian Society for Digital Humanities (founded in 1986 as a consortium for computers in humanities), Internet network of Digital Humanities Centers (CenterNet), the Australasian Association for Digital Humanities (AADH) and the Japanese Association for Digital Humanities. The ADHO's members are independent scientists, students, postgraduates and researchers from all over the world (The Alliance of Digital Humanities Organizations (ADHO) [18]. An important feature of the Alliance is a publication of a quarterly journal on digital humanities (Digital Humanities Quarterly (DHQ) - a digital journal with open access that covers all aspects of digital media in the humanities: experimenting with different formats of publications and rhetoric about digital publishing of articles on literary and linguistic computerization (well-established printing of digital humanities journals) in ways that overcome the print and digital gap; using open standards to deliver the content of the magazine; developing translation services and multilingual review in accordance with international character of ADHO. The wide range of reviewed materials is published in the journal, including: scientific articles, edited works with alternative ideas; experiments in interactive media; book reviews, web-sites, new media-art installations, digital humanistic systems and tools [27].

In the field of digital humanities pedagogy occupies a leading position as its role meets the challenges of the modern information society about the need for lifelong education of people in accessible for them formats of formal and informal education. The objective of digital humanistic pedagogy is to create concepts of integration of humanistic and technological components of the educational process, defining ways to use ICT to improve the quality of teaching, giving it the properties of democracy, openness, personalization, creativity, encouraging everyone to cognitive learning activities. In this context, B. D. Hirsch emphasizes: "if digital humanities fully realized its potential to change the current academic approaches to teaching, digital humanistic pedagogy should be moved from marginalization and isolation to the forefront of research" [26].

The foreign scientists outline that the use of ICT in teaching involves analysis of pedagogical changes caused by their use. In other words, as Paul Fyfe emphasizes, this means that "lecturing technology (for example, PowerPoint) without thinking of how lecture form should be developed and enriched is not enough. Teachers need to think integrally about different functions of a modern teacher in realities of digital life in both academic and nonacademic spaces" [28].

Thus, due to the convergence of technological and humanistic areas of knowledge, in foreign educational practices a new category of "digital humanistic pedagogy" and a new scientific branch appeared, characterized by a set of ideas, concepts that have been formed not in related, but in independent, technocratic and humanistic fields of research.

Based on the analysis of foreign and national experience of convergence of ICT with humanistic-educational practices we suggest using category "digital humanistic pedagogy" emphasizing on development of a human personality through ICT. In broad terms, digital 
humanistic pedagogy is the science about rules of transmission and perception of educational experience that happens in physical and virtual realities through the use of ICT, including digital technologies.

Examples of practical application of digital humanistic pedagogy can be analyses of educational phenomena that occur when using ICT (Power Point, social media, networks, blogs, websites, etc.) for training representatives of different age groups and different professional directions.

In this case ICT is interpreted not only as an up-to-date means to illustrate educational information. Competent teachers using ICT implement a number of important educational and didactic, organizational and creative functions: expansion of channels of transmission and reception of information; promotion and development of cognitive processes; achievement of democratization, transparency, personalization, interactivity, flexibility and access to learning, creative self-realization, and self-identity. Pedagogical analysis of the use of ICT as a tool for implementation of educational-research, student-centered education confirms positive changes in convictions of teachers; and it affects and alters the shape and nature of teaching and learning.

It is important for teachers to understand the peculiarities of educational events in the convergence of physical and virtual spaces of different types of teaching, evaluate expansion of cognitive opportunities offered in the modern world. Philosophers emphasize the fact that a person had the opportunity through ICT to meet a critical need of the human spirit associated with break through beyond the real, in another world - the virtual. Fleeing from the boredom of everyday life, people are deep in the virtual reality of television, computer monitor, cell phone, CD-player and they turn over Internet pages trying to solve problems of the physical reality.

Consciousness of an individual gets heterogeneity that includes along with "everyday reality" a number of other not everyday realities. There are so-called transreality transitions complete, "when new reality gets full ontological status", or incomplete. The ability to such transitions, to combine realities is an essential element of processes of socialization, development of an individual in the modern society [5, p. 119]. In this regard, there is urgent need for researching virtual events, learning opportunities for their use in creating an effective teaching environment, using ICT to enhance virtual characteristics of teaching reality.

In this context, such concepts as reality and imagination, being and consciousness, natural and artificial, real and fantastic, humanistic and technocratic have gained new meaning. It is due to deepening scientific understanding of the world as a set of realities, which partly overlap and interact with each other, including overall educational space and partial teaching environments.

Pedagogical reality is determined by space and time, where an individual acquires some experience. As a multidimensional phenomenon, it combines rational and sensual, conscious and unconscious, biological and technological, real and imaginary, and can acquire spiritual and creative, but at the same time destructive characteristics. Pedagogical reality covers all areas of life in the society of knowledge, lifelong learning and has to become a subject of the detailed study of pedagogy.

According to the classical pedagogical thought, a teacher creates a special environment that has to impact positively on students, provides them with training, education and development. We more and more deeply understand the fact that it is difficult, almost impossible to train and develop an individual if he/she actively counteracts this process. The success of teaching depends on how it motivates students to self-education. If a student doesn't actively participate in educational activities and enjoy the cognitive actions, such training will hardly lead to positive changes in his/her personality. So, crucial are the characteristics of learning environment that can encourage an individual to cognitive activity, 
intensify it or repel from it. In this case an extremely important factor is how this cognitive activity meets the personal needs, directs a student to possible ways of self-completion, which improve the quality of life.

All the above mentioned information is of particular importance for the development of model of pedagogical reality, which uses ICT for positive effect on an individual [11]. In this context, a teacher must gain proficiency in pedagogical mastery that combines knowledge about origins of pedagogical reality, rules of its creation and research, awareness of the role of ICT in these processes, as well as practical skills for their implementation.

The nature of pedagogical reality, special features of its effect on an individual is characterized by the author's theory of cognitive and active field [12]. The human communication in general, including teacher-student communication takes place in space and time, so it can be described as a category of cognitive and active field. The definition "cognitive and active field" is universal.

Any activity takes place in the coordinates of cognitive and active field. The philosophical support of this statement is found in the concept of academician V. I. Vernadsky about scientific thought as a planetary phenomenon of space character. The remarkable moment of V. I. Vernadsky's concept is the statement that an individual exists as long "as material and energy exchange occurs" between him/her and the environment in which he/she lives [4]. According to V. I. Vernadsky, energy and material exchange between living organisms is realized through "the field of life - both in the environment of universal gravitation and a microscopic section, where gravity force is not dominant..." $[4,9]$. According to V. I. Vernadsky, each person is characterized by "the field of own existence", for which rational and irrational elements are natural.

Thus, the field of an individual is characterized by a combination of sense and rational, conscious and unconscious, heuristic and hedonistic. It manifests itself in people's attitude to the world, as well as phenomena that defy standard logical comprehension: emotions, feelings, experiences, intuitive forecasts, special scientific thoughts, inspirations, fantasies, dreams and more.

The field of an individual is in the constant interaction with the fields of others. In our opinion, when a group of people integrates in order to perform a certain activity, there is a phenomenon of imposing of individual fields and there is a total field of activity. If pedagogical activity is considered as a process of teacher-student energy and material exchange, it is right to make conclusion about the presence of communicative field of cognitive-active character or cognitive-active field, which is the result of blending personal fields of a teacher and students during a particular lesson or lessons.

Let us consider the process of creating cognitive-active field by a teacher. As a subject of the educational process, a teacher provides information of subjective characteristics. It is not about the content of educational material deformation. We note that this content is submitted to a certain sensory-emotional manner. This sensory-emotional manner occurs in the imagination of a teacher. According to Paracelsus - the famous philosopher, alchemist and physician of the XVI century, "Imagination is a sun of the human soul ... If the power of imagination is enough to illuminate the entire inner world of an individual, his/her imagination can create". Paracelsus underlined that "imagination is a tool. Through the power of imagination will creates thought forms. Imagination creates action" [12, p. 18]. Through tension of psychic energy (intelligence, emotions, feelings), teacher transmits information image to students. Information image is a source of creation of informative and educational reality, which acts on a student through words, facial expressions, teacher's gestures, means of training, and information and communication technologies that it uses. Thus, teacher is a creator of the information image transmitted to students through words, actions, and information and communication technologies. 
It is possible to determine the power and energy characteristics of the cognitive and active field depending on the product of teacher's creativity. The field can be shown through senses, emotions that are experienced by all participants of educational process. The higher the intensity of feelings, the greater the power characteristic of the field is. Depending on positive (joy, enthusiasm, success, inspiration, love) or negative (fear, humiliation, violence, failure, impotence) feelings, we determine the energy potential of the field - positive or negative. The total energy potential in this class is the sum of energy potentials of the fields of each person, creating a common energy background.

The cognitive and active field of the maximum positive potential is manifested in the special atmosphere of creative enthusiasm of teacher and students when each of them and all together are covered with fine sense of delight, joy, discovery and comprehension of the phenomena previously unknown of surrounding and inner world.

Pedagogical mastery involves finding ways to increase positive energy potential of the field of cognitive activity. It is about mobilizing mental (intellectual and sensory-emotional) resources of each student, their orientation on training. It is important to remember that psychic energy of each person is multiplied by joyful, cheerful, and creative work; difficulties are easier overcome. Thus, the academic work of students should be cheerful, inspirational, creative, joyful, attractive, because only in this condition mental processes are developed and a person experiences a sense of comfort, and emotional satisfaction.

It is necessary to enhance the impact of cognitive and active field in order to make information image learned by a student and the process of its perception ensured psychophysical development of an individual. ICTs play a special role in this process. We emphasize that the strengthening of cognitive and active field on students, mastering information image by them will be provided in the case of expanding channels of perception and processing academic information. This is facilitated by the ability of teachers to expand the channels of transmission, reception and reproduction of information through the use of multimedia and web-oriented technologies. Multimedia presentations of educational information, audio and video materials, network interaction with the subjects of educational process, representatives of various institutions at the individual, local and global levels increase the positive potential of cognitive and active field.

Based on the use of ICT teacher works with new types of "text", genres, new forms of discussion and communication models, new "databases" (hypertexts, infographics, video blogs, Internet communities, and others). They are united by the idea of co-creativity, creation of more open and available resources and unlimited opportunities to exchange information and use it (philosophy of Web 2.0). For example, an electronic text is a more dynamic means of transferring information in comparison with a traditional printed text. The electronic text properties include: volatility and mix of alphabetic and imaginative information. In electronic texta word, image and sound are expressed in a common digital code. An author can save electronic text in the original form, modify it, give it to someone else, but it is still available to the author. The surface of the text is also variable: you can zoom in or zoom out, change placement of the text on the page, configuration of illustrations and form of letters. This feature of electronic text is named by Lenham R. as rhetorical; stressing that electronic text blurs the line between its creator and reader, and stimulates creative self-realization [35, p. 16].

Thus, the positive potential of cognitive and active field will increase dramatically if students acquire information image through their own creative actions with the help of ICT. Attaining the image not only through listening, but also through visual perception, movement (pantomime play), synthesis of speech and motor expression, dramatic play, experimentation with different materials ensures formation and stable storing of information images in the 
imagination of students. Teacher should use technologies that provide creative activity in real and virtual environments.

Pedagogical reality is variable in content and form and gains speech, mathematical, scientific, and artistic features depending on the subject being studied. Skillful use of ICT expands operational opportunities of educational reality and deepens its virtual characteristics that provide:

- journey into the world of mathematical, natural, philological, art, and human concepts;

- inspiration of categories, events, characters, and dialogue with them;

- moving along the time axis and imaginary being in the past eras, the appeal to the experience of people living in different historical periods;

- moving in space and imaginary stay in geographically remote locations;

- transfer into parallel worlds (book, TV, Internet);

- safe experimentation with concepts, phenomena, random selection of actions, activities that do not lead to irreparable consequences;

- correction of events occurred;

- review of events to change their implications;

- creative development of teaching and learning reality from local to global level.

As you can see, teaching and learning reality contains, along with real, virtual elements, that create a strong gravitational field, make learning fun and attractive. In this context, ICTs are used for development of imagination, fantasy, creativity, penetration into the essence of the various phenomena, processes and, importantly, to limit the pressure of everyday life, satisfy needs in finding unusual, hyper real. Teacher who uses ICT knowingly transfers the actions of students in virtual space. Moreover, all participants of the educational process should understand the convention of virtual space created by the real actions and technologies.

It is advisable to use ICT to create effective pedagogical reality. It is expected that a teacher and students do real actions for imaginary movement into created virtual space and perform all activities in it that are inaccessible or impossible for traditional learning environment. Pedagogical reality, which combines real and virtual spaces, creates conditions for spiritual and creative development of teachers and students.

The areas of current studies in the field of digital humanistic pedagogy cover problems of creating and learning integrated pedagogical reality, which combines real and virtual spaces and is an example of the interaction of biological and technological components to ensure quality of education. Methodologically important are issues of finding out the nature of research methods of digital humanistic pedagogy.

The practical use of research methods of digital humanistic pedagogy means the implementation of scientific research at the intersection of digital and traditional humanistic means. And this is implemented in two different ways. On the one hand, digital tools and technologies for traditional humanistic studies are applied. On the other hand, humanistic research methods are used to study educational phenomena occurring in mixed or virtual environments created by digital technologies. The use of ICT for educational research, including the use of video surveillance, audio and video recording, allows you to travel in space and time, creates conditions for fixing the entire complex of reactions studied, and raises qualitative research to a new level, progress and results of which in digitized (electronic) form can be stored in the memory of the computer and when needed play a full picture of the events, becoming a source of new research. Audio and video recording is often used when interviewing, observing, experimenting, and creating digital narratives.

In schools where the video surveillance systems are installed, ICTs help perform preventive educational function. After all, when students realize that the video surveillance is 
conducted in school, they are more disciplined and punctual. Teachers use the records to analyze the educational process, and create digital educational or entertaining stories based on the video archive.

Nethnography as a foreign pedagogical approach to research Internet networks is worthy of notice. This notion was introduced by Robert V. Kozinets - the American scientist and inventor of netnography. He formed this notion with two English words: "Internet" ("inter [net]") and "ethnography" [34].

Nethnographyis a branch of ethnography, which studies the behavior of people in the network and is concentrated around cultural, symbolic and information ideas. The foreign scientists (D. Miller, D. Slater) determine that "ethnography means the long research through the use of various methods to ensure that as many aspects of people studied could be properly understood or conceptualized by others" [34].

M. Hammersley and P. Atkinson argue that ethnography "in its the most typical form requires the anthropologist participation, which is explicit or latent in everyday life of people over a long period, observation of the events, listening to conversations, asking questions - in other words, it requires collecting all available data that will shed light on the problem that is the subject of research". A similar approach is being implemented during the ethnographic research, which completely or partly takes place in the Internet and is called nethnographic research. The methods such as observation, participation in the life of a particular community, communication with its members and asking questions pertaining to their behavior are used by scientists who conduct research in the Internet [32].

According to Christina Hine, the author of the classic work "Virtual ethnography", if people, who are being studied, transfer certain aspects of their lives to the Internet, the researcher must also study the network [33].

Nethnography is used to research the issues that are difficult to study using quantitative methods, in particular: critical assessment of information received from others, sources of information, creative activity, "Internet piracy", activity on the social networking sites, potential of social media as an area for development of information and communication competencies, creating an image in the network, network security, and others.

The nethnographic research involves the gradual implementation of the following six steps: 1) planning; 2) entry into the network; 3) data collection; 4) interpretation, 5) ethical standardization; 6) presentation of the results.

The most common methods of thenethnographic research are the study of individual sites, especially which are popular in the target group studied, and online questionnaires. The use of online questionnaires is seen as a complement of information obtained during the interview and observations. The online questionnaires, despite the undeniable advantages (low cost, fast access to the results, possibility of contact with defined groups), are characterized by serious risks associated with the lack of direct physical presence of the researcher / interviewer. When the research topic is related to the field of taboo, this absence is a huge advantage, whereas during the test, which is completed by young people, it is necessary to reckon with two serious risks: possibility of misunderstanding the question by a respondent and ease of refusal to participate in the study. To neutralize these risks special attention should be paid to the questionnaire structure and the limit of open questions in favor of closed ones.

One of the main dilemmas related to nethnography is the scientist's choice of his/her role in the study. According to the fundamental classifications, roles that researchers can perform are: an observer as a participant - in this case the researcher works "incognito", without revealing his/her true intentions to the members of the community studied; a participant as an observer - the researcher decides to explore the environment in which he/she is accepted and known; an observer who is not a participant; an outsider [33, p. 107-120]. 
During nethnography computer-mediated communication as a source of data to determine the ethnographic nature and presentation of cultural or social phenomenon is used. Thus, the scientific search is carried out in which facts about the subject of research is obtained by selective observation and theoretical interpretation of what we see, and by asking questions and interpreting responses, by streamlining notes and audio or video recordings during preparing scientific reports.

For a more complete picture of learning using ICT, including the Internet network, analytics training is used that combines computer technologies (data and text analysis, data visualization) with pedagogy, social sciences and psychology [30]. According to L. Panchenko, analytics training is a promising direction of research in the field of higher education that aims at improving the learning process, understanding the students and how they learn, making supported decisions on the basis of the analysis of educational data. Analytics training is based on the methods of multivariate research, data analysis, using neural networks, machine learning methods, social network analysis, and data visualization [14]. We emphasize that analytics training has evolved from the area of cyber research and spread on teaching practice, educational management, allowing teachers to carry out a more subtle analysis of the impact of ICT on the various types of social-cognitive activity.

As teachers are increasingly using open educational resources, and a variety of applications are available on mobile devices, so the use of analytics training to track the participation of students in educational activity is becoming increasingly important [30, $\mathrm{p}$. 61]. It is necessary to monitor and evaluate the use of external resources [37]. This information is crucial for the educational support of individual students, and it informs the academic community on possible ways to improve the quality of education. However, the use of students' data may have different consequences, especially in building relationships of trust and respect between institutions and students. As analytical tools become more widely available, there is the growing desire to use them for educational research. In order to gain a better understanding of the impact of the current changes on the educational reality, it is important that, educational establishments develop policies of the use of analytics training for the evaluation of educational and research activities.

Thus, the study on digital humanistic pedagogy involves integrated use of traditional, modernized, and specific methods of implementation of the scientific research.

The important task of digital humanistic pedagogy is enrichment of modern Internet space by transferring educational cultural heritage to the network and giving access to it not only to academic users (researchers, teachers, students, pupils), but also to the general public. The use of methods of digital humanistic pedagogy can add a new dimension to historical and pedagogical research; enable researchers to travel in space and time while analyzing video and audio recordings, and to digitize (transfer in electronic form) unique documentary and epistolary materials, photos, images.

An important area of research of digital humanistic pedagogy is a creative realization of personality in the virtual space. The opinion of R. Lenham sounds reasonable, that children and all citizens need to be taught electronic expression, which is essential for a society of digital information [36, p. 15-16]. In order to fulfill this task in 1993 a center of digital stories at Berkeley was founded. The practice of creating short, personal narratives using ICTs spread to all English-speaking countries and the Western Europe.

We emphasize that narrative is an information message of reflective nature; that is a story that reveals the narrator's position on what he/she says. The use of digital technologies greatly increased the effectiveness of narrative studies. Today, the trend of implementing narrative-digital approach, according to the research results of L. Tymchuk, clearly stands out in all forms of learning (formal and informal) in the international educational space [17]. 
A digital narrative is the practice of using computer technology for storytelling. There are many terms to describe this practice: digital documentaries, digital storytelling, digital essays, electronic memoirs, interactive stories and others. But overall digital narratives relate to the idea of combining art to tell stories with a variety of media, including graphics, audio, video and web publishing [25]. Duration of digital narratives is variable, but in the educational practices, it is from 2 to 10 minutes. Digital narratives cover a wide range oftopics (personal stories, tales, historical events, etc.). It is found that students who participate in the creation of digital stories can improve cognitive and communication skills, they also learn to organize ideas, ask questions, express opinions and build narratives. Placing digital narratives in the Internet, students have an opportunity to share their works with classmates and gain valuable experience in critical analysis of their own works and the works of other students; it contributes to the development of emotional intelligence and encourages social interaction [25].

The problem of studying the features of the use of ICT for organization of health keeping education does not lose its relevance. The scientific research is intended to identify the effective ways to resolve the issues outlined, in particular, it needs to study the use of ICT to enhance cognitive processes, the development of creative skills and coordination of all subjects of health keeping education (teachers, students, parents, and professionals), the use of ICT in teaching children with special needs. Special attention is paid to the study of cognitive, social and communicative skills by creating new personal and meaningful knowledge through the use of ICT.

\section{THE CONCLUSIONS AND PROSPECTS OF FURTHER RESEARCH}

The rapid development of computer tools and ICT, especially digital and fiber-optic ones, their widespread adoption in all spheres of public life accelerated integration and communication processes, provided new and more productive opportunities of combining various branches of knowledge. Digital humanistic pedagogy is not just a new way of teaching; its appearance caused the emergence of a new educational paradigm, and formation of scientific area that is rapidly developing and motivating the emergence of discussions and new pedagogical thinking.

Methodological principles of digital humanistic pedagogy are highlighted in the following statements:

1. The use of ICT in different forms and types of learning activities of students of different age groups should be directed at providing educational process with cognitive and creative characteristics, openness, flexibility, democratization, differentiation, personalization, and comfort;

2. The development of teachers' integrated thinking, which is aimed at the perception, planning, implementation and evaluation of the educational process that occurs through a combination of human resources and ICT, is a necessary condition for ensuring the quality of education in the information society;

3. The teachers' awareness of opportunities to use ICT to create positive educational reality, characterized by cognitive and active field, is an important motivational factor of professional activity;

4. The teachers' ability to expand channels of transmission, reception and reproduction of information through the use of ICT reinforces the effect of cognitive and active field on students, and improves students' learning of information image;

5. The positive potential of cognitive and active field will dramatically increase if students acquire information image by experimenting with different ICTs; and it will ensure creative activity in an integrated (real and virtual) learning environment; 
6. The skillful application of ICT expands operational capacity of educational reality, deepens its virtual characteristics; and it creates conditions for spiritual and creative development of teachers and students;

7. For the diagnosis and evaluation of the quality of the educational process, which is implemented in the interaction between human and information technology components, along with traditional methods of research, the methods of scientific analysis of students' activity in the virtual space should be applied.

The problems of development of digital humanistic pedagogy, understanding it as an important component of lifelong education, the implementation of its educational potential in the information society need further research.

\section{REFERENCES (TRANSLATED AND TRANSLITERATED)}

1. Abstracts and dissertations defended at Specialized Counsil in the Institute of Information Technologies and Learning Tools of NAES of Ukraine within specialty 13.00.10 - information and communication technologies in education [online]. - Available from: http://iitlt.gov.ua/atestat/spetsializovana-vchenarada/avtoreferaty-dysertatsiyi.php (in Ukrainian).

2. Bykov V. Yu. Organizational System Models of Open Education : Monograph / V. Yu. Bykov. - K. : Atika, 2009. - 684 p. (in Ukrainian).

3. Bykov V. Yu. Cloud computing technologies, ICT outsourcing and new functions of ICT departments of educational and scientific institutions / V. Yu. Bykov // Information Technologies in Education : Collection of Scientific Papers. - Issue 10. - Kherson : Kherson State University, 2011. - 271 p. - P. 823 (in Ukrainian).

4. Vernadsky V. Scientific thought as a planetary phenomenon / V. Vernadsky. - M. : Nauka, 1991. - 270 p. (in Russian).

5. Voiskunsky A. System of realities: psychology and technology / A. Voiskunsky, M. Selisskaya // Problems of Philosophy. - 2006. - № 11. - P. 119-130 (in Russian).

6. Zhaldak M. I. Humanitarian potential of informatization of educational process / M. I. Zhaldak // Problems of informatization of education : Collection of Scientific Papers. - K. : Min. of Ed. of Ukraine, USPU named after M. P. Dragomanova, 1994. - P. 3-20 (in Ukrainian).

7. Zhaldak M. I. Problems of informatization of educational process in secondary and higher education / M. I. Zhaldak // Computer in school and in family. - № 3. - 2013. - P. 8-15 (in Ukrainian).

8. KreminV. G. Categories "space" and "environment": characteristics of model representation and education using / V. G. Kremin, V. Yu. Bykov // Theory and Practice of social systems management. 2013. - № 2. - P. 3-16 (in Ukrainian).

9. The concept of continuous education content of Computer Science (Project) / Et al. O. A. Pavlov, S. M. Grisha, Y. S. Ramskyy, N. V. Morse, G. L. Yakovlev. - K . : Institute of Syst. Research. - 1994. 24 p. (in Ukrainian).

10. The concept of education informatization / (Et al. V. Yu. Bykov, Y. I. Vovk, M. I. .Zhaldak, Y. S. Ramskyy, N. V. Morze, I. I. Komissarov, M. L. Smulson, Y. I. Maschbyts, V. I. Lugovyi, O. I. Lyashenko, V. D. Rudenko, A. G. Oleinik, A. Y. Pylypchuk) // "Ridna shkola». - № 11. - 1994. - P. 26-29 (in Ukrainian).

11. Leshchenko M. Methodological bases of teachers training to use ICT for creating positive educational reality / M. Leshchenko // Humanization of the educational process : Collection of Scientific Papers / Ed. prof. V.I. Sypchenko. - Vol. LXIX. - Slavyansk. - DDPU, 2014. - P. 5-13 (in Ukrainian).

12. Leshchenko M. Happiness of child: to problem of pedagogical masterpiece / M. Leshchenko. - K. : ASMI, 2003. - 304 p. (in Ukrainian).

13. Ovcharuk O.V. Competency development approach: strategic goals of the international community // Competence approach in modern education: world experience and Ukrainian prospects: Library of Educational Policy / Ed. O.V Ovcharuk. - K. : K.I.S., 2004. - P. 59-65 (in Ukrainian).

14. Panchenko L. F. The training of future professionals for the implementation of educational analysts / L. F. Panchenko. // Bulletin of KrNU named after Mykhailo Ostrohradskyi. Series of "Pedagogical Science". - Issue 1/2015 (2). - P. 80-85 (in Ukrainian).

15. The passport of the specialty 13.00 .10 - ICT in education [online]. - Available from: http://iitlt.gov.ua/atestat/spetsializovana-vchena-rada/pasport-spetsial\%60nisti-13-00-10-informatsiynokomunikatsiyni-tekhnologiyi-v-osviti.php (in Ukrainian). 
16. Spirin O. M. ICT training, internal quality evaluation criteria [online] / O. M. Spirin // Information technologies and tools of teaching. - 2010. - № 5 (19). - Available from: http://journal.iitta.gov.ua/index.php/itlt/article/view/358/315 (in Ukrainian).

17. Tymchuk L. Narrative education in media space / L. Tymchuk // Pedagogical science: theory, history, innovative technology. - №3 (37). - 2014. - P. 355-368 (in Ukrainian).

18. The Alliance of Digital Humanities Organizations [online]. - Available from: http://adho.org/ (in English).

19. Anderson P. What is web 2.0? Ideas, technologies, and implications for education // Technology and Standards Watch. - 2007. - P. 1-64 (in English).

20. Bellamy C. The Sound of Many Hands Clapping: Teaching the Digital Humanities through Virtual Research Environments (VREs) / Craig Bellamy // Digital Humanities Quarterly. - 6.1. - 2012 (in English).

21. Bjork O. Digital Humanities and the First-Year Writing Course / Olin Bjork // Digital Humanities Pedagogy: Practices, Principles and Politics / Brett D. Hirsch, ed. - Cambridge : UK, Open Book Publishers, 2012 (in English).

22. Brier S. Where's the Pedagogy? The Role of Teaching and Learning in the Digital Humanities [online] / S. Brier // Debates in the Digital Humanities : University of Minnesota Press, 2012. - 504 p. - Available from: http://dhdebates.gc.cuny.edu/debates/text/8 (in English).

23. Clement T. Multi literacies in the Undergraduate Digital Humanities Curriculum: Skills, Principles, and Habits of Mind / T. Clement // Digital Humanities Pedagogy: Practices, Principles and Politics / Brett D. Hirsch, ed. - Cambridge : UK, Open Book Publishers, 2012 (in English).

24. Davidson C. N. Collaborative Learning for the Digital Age / Davidson Cathy N. // The Chronicle of Higher Education. - 2011 (in English).

25. Diamond M. E. The role of narrative in multimedia learning / Diamond Myrna Elyse // Capstones Paper 1231. - University of Nevada, Las Vegas. - 2011. - 200 p. (in English).

26. Digital Humanities Pedagogy: Practices, Principles and Politics [online] / Brett D. Hirsch (ed). Cambridge: Open Book Publishers, 2012. - 426 p. - Available from: http://www.amazon.com/DigitalHumanities-Pedagogy-Practices (in English).

27. Digital Humanities Quarterly [online]. - Available from: www.digitalhumanities.org/dhq/.../about.html (in English).

28. Fyfe P. Digital Pedagogy Unplugged [online] // Digital Humanities Quarterly. - Vol. 5, № 3. - 2011. Available from: http://digitalhumanities.org/dhq/vol/5/3/000106/000106.html (in English).

29. Jakacki D. Digital Pedagogy in the Humanities [online]. - Available from: www.dhsi.org/.../7.\%20Digital\%20Pedagogy\%20in\%20the\%20Humanitie (in English).

30. Hack C. Applying learning analytics to smart learning - ethics and policy. Learning analytics [online] // Smart learning: Teaching and learning with smartphones and tablets in post compulsory education / Middleton A., ed. (Media-Enhanced Learning Special Interest Group and Sheffield Hallam University). 2015. - 300 p. - Available from: http://melsig.shu.ac.uk/?page_id=503 (in English).

31. Humanistyka drugiej generacji na UKW [online]. - Available from: www.rekrutacja.ukw.edu.pl/ (in Polish).

32. Hammersley A. Metody badań terenowych / A. Hammersley, P. Atkinson. - Poznań: WydawnictwoZysk i S-ka, 2000. - 207 p. (in Polish).

33. Hine Ch. Virtual Ethnography / Hine Ch. - London-Thousand Oaks-New Delhi : SAGEPublications, 2007. - 112 p. (in English).

34. Kozinets R.V. Netnography. Doing ethnographic research online / R.V. Kozinets. - Los Angeles-LondonNewDelhi-Singapore-Washington DC : SAGE Publications, 2010. - 127 p. (in English).

35. Lanham R. The Electronic Word: Democracy, Technology, and the Arts / R. Lanham. - Chicago : The University of Chicago Press, 1993. - 373 p. (in English).

36. Mahony S. Teaching Skills or Teaching Methodology? S. Mahony, E. Pierazzo // Digital Humanities Pedagogy: Practices, Principles and Politics / Brett D. Hirsch, ed. - Cambridge: UK, Open Book Publishers, 2012. (in English).

37. Scheffel M. Quality Indicators for Learning Analytics / Scheffel M., Drachsler H., Stoyanov S., Specht M. // Educational Technology \& Society. - 17 (4). - 2014. - P. 117-132. (in English).

38. Technology use in health education: A review and future implications [online] / Holly M., Satterfield M., ed. // The Online Journal of Distance Education and e-Learning. - 2015. - Vol. 3, Issue 2. - P. 87-96. Available from: www.tojdel.net Copyright. (in English).

39. Universytet Jana Kochanowskiego w Kielchah Filia w Piotrkowie Trybunalskim [online]. - Available from: www.unipt.pl. (in Polish). 
40. Warnock S. Introduction: Migrating to Online Writing Instruction: How, Why, and Who / S. Warnock // Teaching Writing Online: How \& Why. - National Council of Teachers of English. - 2009. - P. IXXXVI. (in English).

41. Whitson R. Where's the Pedagogy in Digital Literary Studies? / R. Whitson [online]. - Available from: http://www.rogerwhitson.net/?p=1947 (in English).

Матеріал надійшов до редакиї 04.06.2016 p.

\title{
ЦИФРОВА ГУМАНІСТИЧНА ПЕДАГОГІКА: АКТУАЛЬНІ ПРОБЛЕМИ ПЕДАГОГІЧНИХ ДОСЛІДЖЕНЬ У ГАЛУЗІ ВИКОРИСТАННЯ ІКТ В ОСВІТІ
}

\author{
Биков Валерій Юхимович \\ доктор технічних наук, професор, дійсний член НАПН України, директор \\ Інститут інформаційних технологій і засобів навчання НАПН України, м. Київ, Україна \\ bykov@iitlt.gov.ua
}

\section{Лещенко Марія Петрівна}

доктор педагогічних наук, професор, провідний науковий співробітник

Інститут інформаційних технологій і засобів навчання НАПН України, м. Київ, Україна

leschenko@iitlt.gov.ua

\begin{abstract}
Анотація. У статті схарактеризовано теоретико-методологічні засади цифрової гуманістичної педагогіки - науки про закономірності створення позитивної інтегрованої педагогічної реальності за умови конвергенції фізичного та віртуального (створеного за допомогою ІКТ) навчальних просторів (середовищ) На основі використання сучасних IКТ навчальна діяльність (формальна, неформальна та інформальна) відбувається на перетині двох світів: реального і віртуального. Звертається увага на те, що методологія й методи педагогічних досліджень класичної педагогіки потребують перегляду й удосконалення в контексті сучасних реалій навчально-виховного процесу, потреб та інтересів усіх його суб'єктів.

У статті проаналізовано розвиток цифрової гуманістики у міжнародному освітньому просторі, окреслено зміст нової галузі педагогічного знання як складової цифрових гуманістичних досліджень, визначено методи й актуальні напрями наукового пошуку.
\end{abstract}

Ключові слова: гуманістика; цифрові технології; інформаційно-комунікаційні технології; інтеграція; цифрова гуманістична педагогіка; методологічні засади; педагогічна реальність; пізнавально-активне поле; якість освіти.

\section{ЦИФРОВАЯ ГУМАНИСТИЧЕСКАЯ ПЕДАГОГИКА: АКТУАЛЬНЫЕ ПРОБЛЕМЫ ПЕДАГОГИЧЕСКИХ ИССЛЕДОВАНИЙ В ОБЛАСТИ ИСПОЛЬЗОВАНИЯ ИКТ В ОБРАЗОВАНИИ}

\author{
Быков Валерий Юхимович \\ доктор технических наук, профессор, Академик НАПН Украины, директор \\ Институт информационных технологий и средств обучения НАПН Украины, г. Киев, Украина \\ bykov@iitlt.gov.ua
}

\section{Лещенко Мария Петровна}

доктор педагогических наук, профессор, ведущий научный сотрудник

Институт информационных технологий и средств обучения НАПН Украины, г. Киев, Украина leschenko@iitlt.gov.ua

\footnotetext{
Аннотация. В статье охарактеризованы теоретико-методологические основы цифровой гуманистической педагогики - науки о закономерностях создания положительной интегрированной педагогической реальности при конвергенции физического и виртуального (созданного с помощью ИКТ) учебных пространств (сред). На основе использования современных ИКТ учебная деятельность (формальная, неформальная и информальная) происходит на пересечении двух миров: реального и виртуального. Сконцентрировано внимание на том, что методология и методы педагогических
} 
исследований классической педагогики требуют пересмотра и совершенствования в контексте современных реалий учебно-воспитательного процесса, потребностей и интересов всех его субъектов.

В статье проанализировано развитие цифровой гуманистики в международном образовательном пространстве, определено содержание новой отрасли педагогического знания как составляющей цифровых гуманистических исследований, определены методы и актуальные направления научного поиска.

Ключевые слова: гуманистика; цифровые технологии, информационнокоммуникационные технологии; интеграция; цифровая гуманистическая педагогика; методологические основы; педагогическая реальность; познавательно-активное поле; качество образования.

\section{СПИСОК ВИКОРИСТАНИХ ДЖЕРЕЛ}

1. Автореферати та дисертаційні роботи, захищені у спеціалізованій вченій разі Інституту інформаційних технологій i засобів навчання НАПН України зі спеціальності 13.00.10 інформаційно-комунікаційні технології в освіті [Електронний ресурс]. - Режим доступу: http://iitlt.gov.ua/atestat/spetsializovana-vchena-rada/avtoreferaty-dysertatsiyi.php

2. Биков В. Ю. Моделі організаційних систем відкритої освіти : Монографія / В. Ю. Биков. - К. : Атіка, 2009. - 684 с.

3. Биков В. Ю. Технології хмарних обчислень, ІКТ-аутсорсінг та нові функції ІКТ-підрозділів навчальних закладів і наукових установ / В. Ю. Биков // Інформаційні технології в освіті : Зб. наук. праць. - Вип. 10. - Херсон : ХДУ, 2011. - С.8-23.

4. Вернадский В. Научная мисль как планетное явление / В. Вернадский. - М. : Наука, 1991. - 270 с.

5. Войскунский А. Система реальностей: психология и технология / А. Войскунский, М. Селисская // Вопросы философии. - 2006. - № 11. - С. 119-130.

6. Жалдак M. I. Гуманітарний потенціал інформатизації навчального процесу / М. І. Жалдак // Проблеми інформатизації освіти : 3б. наук. праць. - К. : МО України, УДПУ імені М. П. Драгоманова, 1994. - С. 3-20.

7. Жалдак М. І. Проблеми інформатизації навчального процесу в середніх і вищих навчальних закладах / М. І. Жалдак // Комп’ютер в школі та сім’ї. - № 3. - 2013. - С. 8-15.

8. Кремінь В. Г. Категорії «простір» і «середовище: особливості модельного подання та освітнього застосування / В.Г. Кремінь В.Г., В.Ю.Биков // Теорія і практика управління соціальними системами. - 2013. - № 2. - С. 3-16.

9. Концепція змісту наскрізної освіти з інформатики та обчислювальної техніки (проект) / [О. А. Павлов, С. М. Гриша, Ю. С. Рамський, Н. В. Морзе, Г. Л. Яковлев]. - К. : Інститут сист. дослід. 1994. $-24 \mathrm{c}$.

10. Концепція інформатизації освіти / [В. Ю. Биков, Я. І. Вовк, М. І. Жалдак, Ю. С. Рамський, Н. В. Морзе, І. І. Комісарова, М. Л. Смульсон, Ю. І. Мащбиць, В. І. Луговий, О. І. Ляшенко, В. Д. Руденко, А. Г. Олійник, А. Ю. Пилипчук] // Рідна школа. - № 11. - 1994. - С. 26-29.

11. Лещенко М. П. Методологічні засади підготовки майбутніх учителів застосовувати ІКТ для творення позитивної педагогічної реальності / М. П. Лещенко // Гуманізація навчально-виховного процесу : зб. наук. праць [За заг. ред. проф. В. І. Сипченка]. - Вип. LXIX. - Слов’янськ. - ДДПУ, 2014. - C. 5-13.

12. Лещенко М. П. Щастя дитини: до проблеми педагогічної майстерності / М. П. Лещенко. - К. : ACMI, 2003. - 304 c.

13. Овчарук О. В. Розвиток компетентнісного підходу: стратегічні орієнтири міжнародної спільноти // Компетентнісний підхід у сучасній освіті: світовий досвід та українські перспективи : Бібліотека 3 освітньої політики / Під заг. ред. О. В. Овчарук. - К. : К.І.С., 2004. - С. 59-65.

14. Панченко Л.Ф. Підготовка майбутніх фахівців 3 інформаційних технологій до здійснення навчальної аналітики / Л. Ф. Панченко // Вісник КрНУ імені Михайла Остроградського. Серія «Педагогічні науки». - Вип. 1/2015 (2). - С. 80-85.

15. Паспорт спеціальності 13.00.10 - інформаційно-комунікаційні технології в освіті [Електронний pecypc]. - Режим доступу: http://iitlt.gov.ua/atestat/spetsializovana-vchena-rada/pasportspetsial\%60nisti-13-00-10-informatsiyno-komunikatsiyni-tekhnologiyi-v-osviti.php.

16. Спірін О. М. Інформаційно-комунікаційні технології навчання: критерії внутрішнього оцінювання якості [Електронний ресурс] / О. М. Спірін // Інформаційні технології і засоби навчання. - 2010. № 5 (19). - Режим доступу: http://journal.iitta.gov.ua/index.php/itlt/article/view/358/315.

17. Тимчук Л. Наративне навчання у медіа-просторі / Л. Тимчук // Педагогічні науки: теорія, історія, інноваційні технології. - № 3 (37). - 2014. - С. 355-368. 
18. The Alliance of Digital Humanities Organizations [online]. - Available from: http://adho.org/.

19. Anderson P. What is web 2.0? Ideas, technologies, and implications for education // Technology and Standards Watch. - 2007. - P. 1-64.

20. Bellamy C. The Sound of Many Hands Clapping: Teaching the Digital Humanities through Virtual Research Environments (VREs) / Craig Bellamy // Digital Humanities Quarterly. - 6.1. - 2012.

21. Bjork O. Digital Humanities and the First-Year Writing Course / Olin Bjork // Digital Humanities Pedagogy: Practices, Principles and Politics / Brett D. Hirsch, ed. - Cambridge : UK, Open Book Publishers, 2012.

22. Brier S. Where's the Pedagogy? The Role of Teaching and Learning in the Digital Humanities [online] / S. Brier // Debates in the Digital Humanities : University of Minnesota Press, 2012. - 504 p. - Available from: http://dhdebates.gc.cuny.edu/debates/text/8

23. Clement T. Multi literacies in the Undergraduate Digital Humanities Curriculum: Skills, Principles, and Habits of Mind / T. Clement // Digital Humanities Pedagogy: Practices, Principles and Politics / Brett D. Hirsch, ed. - Cambridge : UK, Open Book Publishers, 2012.

24. Davidson C. N. Collaborative Learning for the Digital Age / Davidson Cathy N. // The Chronicle of Higher Education. - 2011.

25. Diamond M. E. The role of narrative in multimedia learning / Diamond Myrna Elyse // Capstones Paper 1231. - University of Nevada, Las Vegas. - 2011. - 200 p.

26. Digital Humanities Pedagogy: Practices, Principles and Politics [online] / Brett D. Hirsch (ed). Cambridge: Open Book Publishers, 2012. - 426 p. - Available from: http://www.amazon.com/DigitalHumanities-Pedagogy-Practices

27. Digital Humanities Quarterly [online]. - Available from: www.digitalhumanities.org/dhq/.../about.html

28. Fyfe P. Digital Pedagogy Unplugged [online] // Digital Humanities Quarterly. - Vol. 5, № 3. - 2011. Available from: http://digitalhumanities.org/dhq/vol/5/3/000106/000106.html

29. Jakacki D. Digital Pedagogy in the Humanities [online]. - Available from: www.dhsi.org/.../7.\%20Digital\%20Pedagogy\%20in\%20the\%20Humanitie

30. Hack C. Applying learning analytics to smart learning - ethics and policy. Learning analytics [online] // Smart learning: Teaching and learning with smartphones and tablets in post compulsory education / Middleton A., ed. (Media-Enhanced Learning Special Interest Group and Sheffield Hallam University). 2015. - 300 p. - Available from: http://melsig.shu.ac.uk/?page_id=503

31. Humanistyka drugiej generacji na UKW [online]. - Available from: www.rekrutacja.ukw.edu.pl/.

32. Hammersley A. Metody badań terenowych / A. Hammersley, P. Atkinson. - Poznań: WydawnictwoZysk i S-ka, 2000. - 207 p.

33. Hine Ch. Virtual Ethnography / Hine Ch. - London-Thousand Oaks-New Delhi : SAGEPublications, 2007. - 112 p.

34. Kozinets R.V. Netnography. Doing ethnographic research online / R.V. Kozinets. - Los Angeles-LondonNewDelhi-Singapore-Washington DC : SAGE Publications, 2010. - 127 p.

35. Lanham R. The Electronic Word: Democracy, Technology, and the Arts / R. Lanham. - Chicago : The University of Chicago Press, 1993. - 373 p.

36. Mahony S. Teaching Skills or Teaching Methodology? S. Mahony, E. Pierazzo // Digital Humanities Pedagogy: Practices, Principles and Politics / Brett D. Hirsch, ed. - Cambridge: UK, Open Book Publishers, 2012.

37. Scheffel M. Quality Indicators for Learning Analytics / Scheffel M., Drachsler H., Stoyanov S., Specht M. // Educational Technology \& Society. - 17 (4). - 2014. - P. 117-132.

38. Technology use in health education: A review and future implications [online] / Holly M., Satterfield M., ed. // The Online Journal of Distance Education and e-Learning. - 2015. - Vol. 3, Issue 2. - P. 87-96. Available from: www.tojdel.net Copyright.

39. Universytet Jana Kochanowskiego w Kielchah Filia w Piotrkowie Trybunalskim [online]. - Available from: www.unipt.pl.

40. Warnock S. Introduction: Migrating to Online Writing Instruction: How, Why, and Who / S. Warnock // Teaching Writing Online: How \& Why. - National Council of Teachers of English. - 2009. - P. IXXXVI.

41. Whitson R. Where's the Pedagogy in Digital Literary Studies? / R. Whitson [online]. - Available from: http://www.rogerwhitson.net/?p=1947

Conflict of interest. The authors have declared no conflict of interest.

\section{(c) EY-NC-SA}

This work is licensed under Creative Commons Attribution-NonCommercial-ShareAlike 4.0 International License. 